\title{
Two-stage hybrid open-endovascular repair of a Crawford type IV aortic aneurysm: therapeutic challenge
}

\author{
Tratamento híbrido (debranching) de aneurisma tóraco-abdominal \\ tipo IV de Crawford: desafio terapêutico
}

Abdo Farret Neto ${ }^{1,2}$, Liana Berucia Freire de Oliveira², Guilherme Tarso de Andrade Alves², George Anderson da Penha Andrade ${ }^{2}$ Eduardo Dantas Baptista de Faria ${ }^{1,2}$

\begin{abstract}
We present a case of a patient with Crawford type IV aortic thoracoabdominal aneurysm. The patient underwent hybrid repair in two stages. Initially a Dacron ${ }^{\circledR}$ graft was implanted surgically with revascularization of all visceral branches from the left external iliac artery (debranching). On a later date, the second stage of treatment was with an endovascular technique with bi aorto-iliac endoprosthesis. After 2 years the patient remains asymptomatic and in full working activity.
\end{abstract}

Keywords: aortic aneurysm; surgery; aorta; aneurysm.

\section{Resumo}

Apresentamos o caso de um paciente com aneurisma aórtico tóraco-abdominal tipo IV de Crawford submetido à correção híbrida em dois estágios. Inicialmente submetido a implante cirúrgico de prótese de Dacron ${ }^{\circledR} \mathrm{com}$ revascularização de todos os ramos viscerais a partir da ilíaca externa esquerda (debranching) e, posteriormente, tratado pela técnica endovascular com endoprótese aorto bi-ilíaca. Após dois anos, o paciente permanece assintomático e em plena atividade laborativa.

Palavras-chave: aneurisma aórtico; cirurgia; aorta; aneurisma.

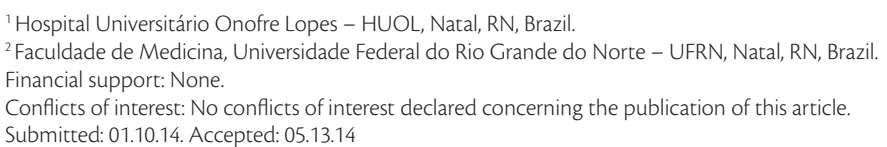




\section{INTRODUCTION}

There is still no consensus on the best form of surgery for Crawford type IV aortic aneurysms (AA), whether open surgery, endovascular treatment or a hybrid technique. ${ }^{1-5}$ In 1999, QuiñonesBaldrich et al. ${ }^{6}$ described the first case of treatment of type IV AA in a combination approach using both conventional surgery and endovascular surgery, during the same operation. A few years later, Chiesa et al. ${ }^{7}$ described a two-stage hybrid approach to treating the same type of AA.

We describe the case of a patient with Crawford type IV AA treated using a hybrid technique in two separate operations. In the first operation, a Dacron ${ }^{\circledR}$ graft was placed in the left external iliac and revascularization of the visceral branches accomplished. In the second operation, endovascular repair of the aneurysm was performed, followed by repair of stenosis at the anastomosis of the right renal artery.

\section{PART I - CLINICAL PRESENTATION}

The patient was a 49-year-old male ex-smoker with diabetes and high blood pressure. He reported a history of severe abdominal pains 3 years previously. On that occasion he had had an abdominal tomography without contrast, which had shown an abdominal aorta aneurysm (AAA) of unknown size. An angiotomography (ACT) conducted in October of 2011 showed that the patient had a thoracoabdominal aneurysm (TAA) measuring $8.47 \mathrm{~cm}$ at its largest diameter, involving the celiac trunk and abdominal visceral branches and extending to the aortic bifurcation (Crawford IV) (Figures 1 and 2).

\section{PART II - WHAT WAS DONE}

The patient underwent open surgery for visceral revascularization on 12 December, 2011, and a $14 \times 7$ mm bifurcated Dacron ${ }^{\circledR}$ Hemashield ${ }^{\circledR}$ graft was implanted (InterVascular, La Ciotat Cedex, France). Access was via a median xiphopubic incision, with medial retraction of the retroperitoneal space from the left paracolic gutter (Mattox maneuver).

The main body of the graft was anastomosed endto-side (ETS) to the left external iliac. Its left branch was anastomosed ETS to the left renal and end-to-end (ETE) to the celiac trunk. The right branch of the bifurcated graft was anastomosed ETE to the right renal artery. A straight segment of $7 \mathrm{~mm}^{\text {Dacron }}{ }^{\circledR}$ graft was anastomosed ETS to the right branch of the prosthesis and ETE to the superior mesenteric (Figure 3). The inferior mesenteric had a small

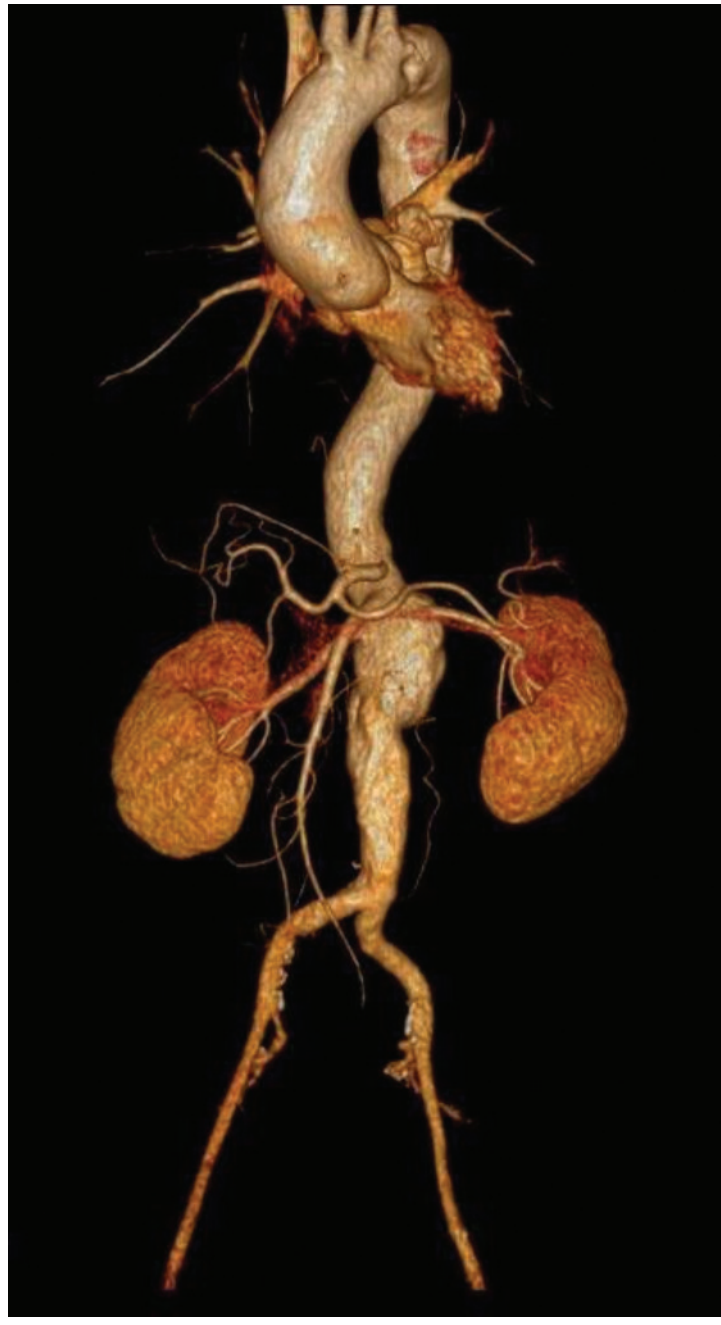

Figure 1. Angio $C T$ in $3 D$ reconstruction, showing the TAA.

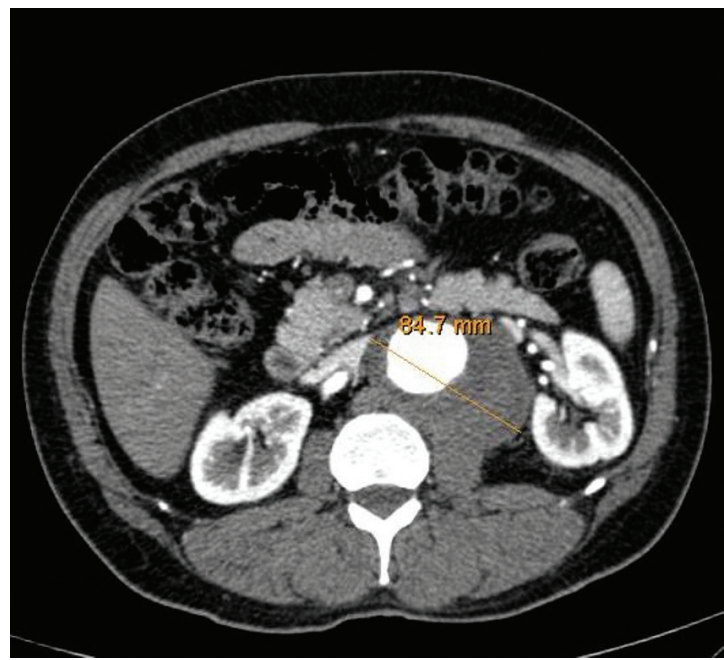

Figure 2. Angio $C T$, axial slice, showing TAA with $8.47 \mathrm{~cm}$ diameter. 


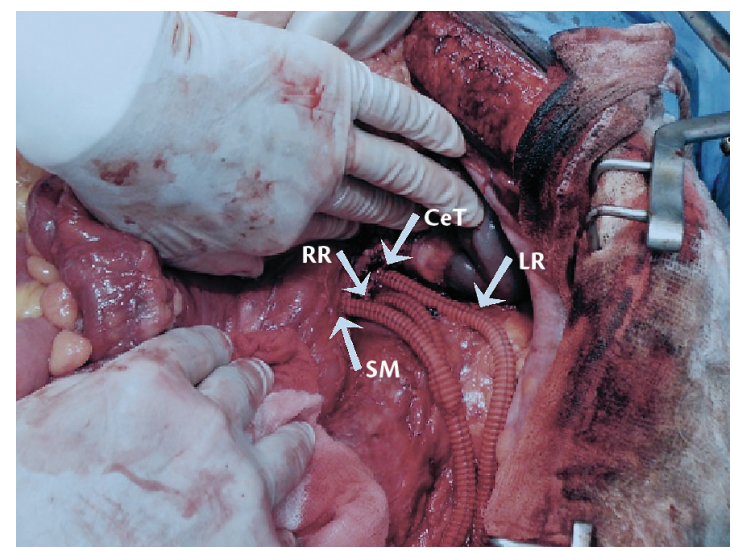

Figure 3. Transoperative image showing revascularization of visceral branches, such as celiac trunk (CeT), right renal (RR), left renal (LR) and superior mesenteric (SM).

caliber and was not revascularized, but was ligated at its origin.

The patient remained stable during surgery, with adequate diuresis and with no need for transoperative blood transfusion. However, during the first 24 hours after surgery, the patient developed signs of hypovolemic shock, with reduced diuresis, hypotension and abdominal distension. An ACT showed a large quantity of liquid free in the cavity and good flow through the grafts (Figure 4). The patient was transfused and underwent abdominal laparotomy, which found around $2,000 \mathrm{~mL}$ of blood in the cavity. Visceral perfusion was adequate and all branches implanted were patent. No sites of active bleeding were identified during reoperation.

The patient continued to exhibit hemodynamic stability, plus acute renal failure due to hypovolemic shock. Renal failure was treated with hemodialysis sessions for 7 days. On the ninth day, after return of adequate diuresis and improvement in renal function with normalization of creatinine levels, the patient underwent surgery to place an endoprosthesis for aneurysm repair.

Transoperative angiography showed stenosis at the anastomosis of the right renal artery, which was treated by placement of a Viabahn ${ }^{\circledR} 9 \times 50 \mathrm{~mm}$ endoprosthesis (W.L. Gore \& Associates, Arizona, USA) followed by angioplasty with a Passeo- $35^{\circledR}$ $6 \times 40 \mathrm{~mm}$ balloon (Biotronik Ag, Bulach, Switzerland) (Figures 5 and 6).

After repair of the renal stenosis, a $31 \mathrm{~mm} \times 26 \mathrm{~mm}$ $\times 10 \mathrm{~cm}$ conical $\mathrm{TAG}^{\circledR}$ thoracic endoprosthesis was implanted starting at the diaphragmatic segment of the abdominal aorta. Fitted to this, an Excluder ${ }^{\circledR}$ $\mathrm{C}_{3}$ endoprosthesis with a main body measuring

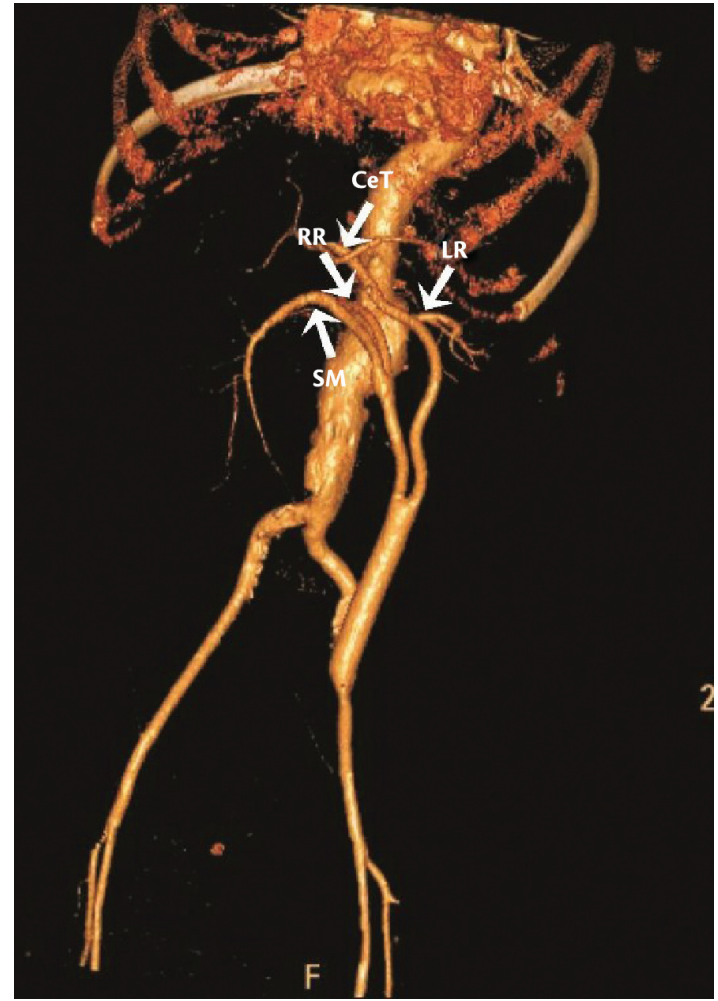

Figure 4. Angio $C T$ in immediate postoperative period showing visceral branches celiac trunk (CeT), right renal (RR), left renal (LR) and superior mesenteric (SM).

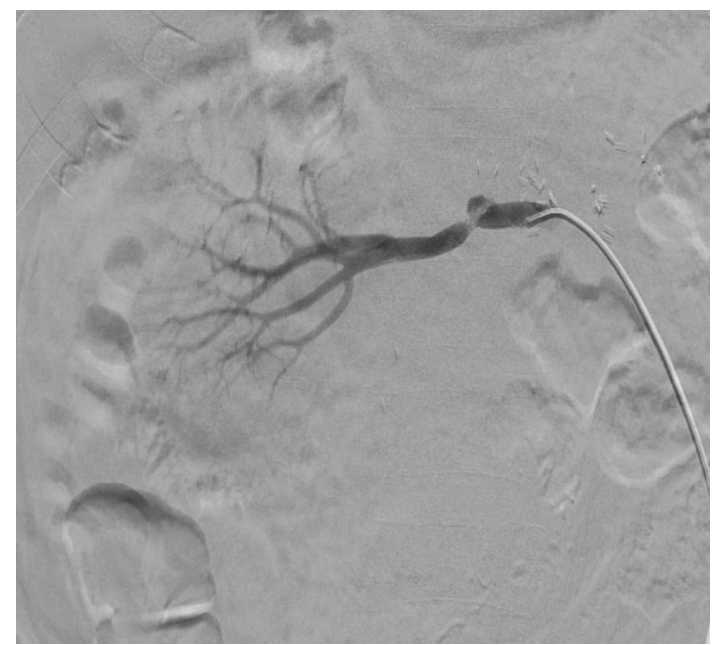

Figure 5. Angiography showing significant stenosis at anastomosis of the right renal artery.

$28.5 \mathrm{~mm} \times 14.5 \mathrm{~mm} \times 16 \mathrm{~cm}$ and an extension measuring $14.5 \mathrm{~mm} \times 10 \mathrm{~cm}$ (W.L. Gore \& Associates, Arizona, USA) was implanted. Segments were fitted to each other using a Tri-Lobe ${ }^{\circledR}$ balloon (W.L. Gore \& Associates, Arizona, USA). The procedure was conducted with no intercurrent 
conditions and the final angiography did not detect any endoleaks (Figure 7).

The patient recovered well, with progressive improvement in renal function and was discharged, asymptomatic, on 30 December, 2011, on his 18th day in hospital.

A control ACT performed on 6 September, 2013, showed that the aneurysm sac was excluded and the

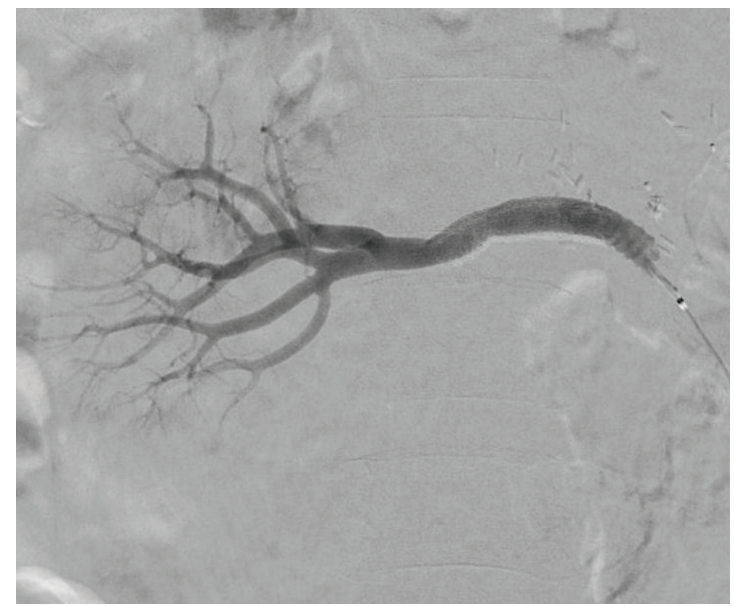

Figure 6. Final appearance after implantation of Viabahn ${ }^{\circledR}$ followed by angioplasty.

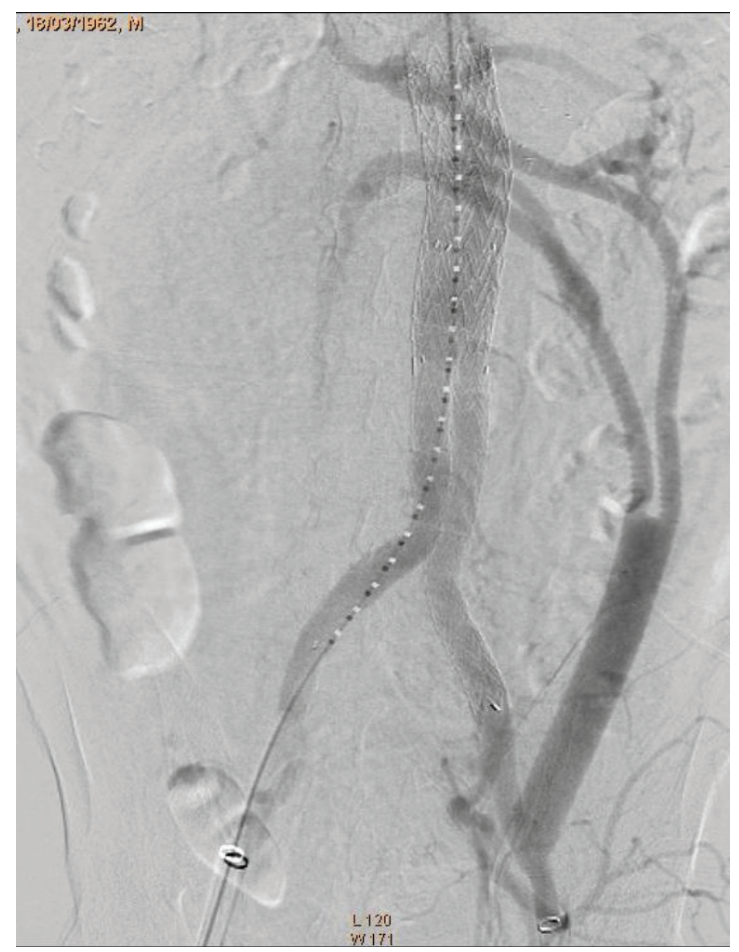

Figure 7. Control angiography after implantation of endoprostheses, showing good visceral flow and absence of endoleaks. grafts remained patent, with no evidence of stenosis or kinking in the branches (Figure 8).

At a recent outpatients follow-up consultation, in December 2013, the patient had returned to full employment, was asymptomatic, except for a complaint of retrograde ejaculation. Renal function was normal and he was still on antihypertensive, antidiabetic and antiplatelet drugs (losartan, amlodipine, metformin and aspirin).

\section{DISCUSSION}

In AA cases with involvement of visceral branches, the possibility of employing endovascular techniques such as multilayer stents ${ }^{8}$ chimney stents, ${ }^{9}$ fenestrated stents ${ }^{10}$ and, particularly, branched endoprostheses, should be considered, although they present therapeutic challenges, with a chance of visceral ischemic complications, endotension and type I endoleaks, ${ }^{11}$ and their long-term durability is unproven. ${ }^{12}$

In this case we chose a combination of conventional surgery with debranching followed by placement of the endoprosthesis, necessary because of complete compromise of the visceral branches. The relatively young age of the patient and his good physical condition were also decisive factors in choosing this technique. These factors suggest good prospects for recovery after conventional by-pass surgery, in addition to a long life expectancy after repair of an AA. We therefore chose the approaches described, because we believed that the visceral bypasses

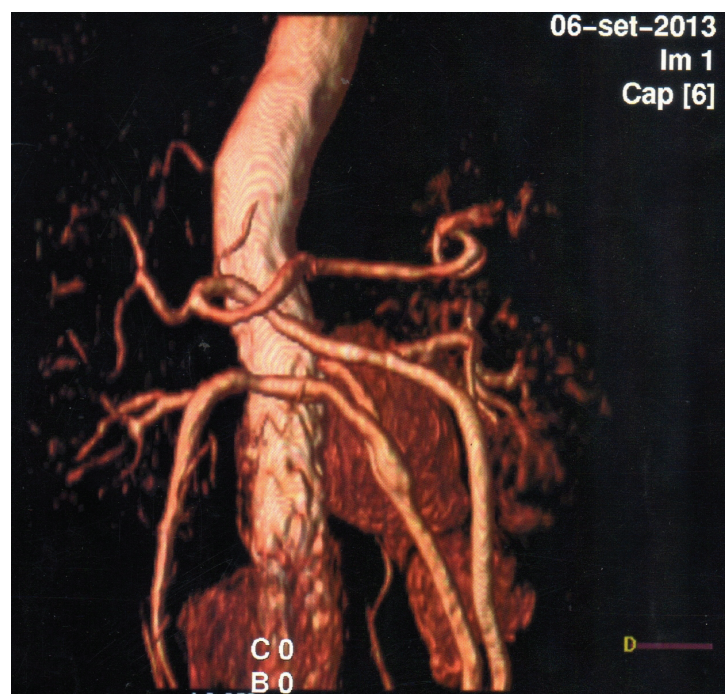

Figure 8. Angio CT 19 months after surgery, showing that the aneurysm sac remains excluded and the visceral grafts are patent. 
would offer greater durability if constructed using conventional surgery. We also chose to avoid conventional endoaneurysmorrhaphy surgery because of the longer duration of visceral ischemia, and greater blood loss and mortality.

Mortality for conventional surgery was around $60 \%$ before 1990 , and current estimates are $4-21 \%{ }^{13,14}$ When hybrid repair techniques, branched and fenestrated prostheses are used, mortality rates of 5.5 to $8.9 \%$ are reported, ${ }^{15-18}$ although the fact that long-term follow-up is lacking should be borne in mind.

The choice of retroperitoneal access via the left paracolic gutter allowed us to place the main body of the Dacron ${ }^{\circledR}$ graft in the left external iliac artery. The choice of the external iliac also facilitated implantation of the endoprosthesis, which was anchored distally at the common iliac artery.

The stenosis at the anastomosis of the right renal artery was treated using a Viabahn ${ }^{\circledR}$ graft to avoid the bleeding that would occur if the recent anastomosis were to be dilated. The angioplasty balloon employed was smaller and shorter than the Viabahn ${ }^{\circledR}$ because we did not wish to injure the unprotected renal artery.

Concluding, hybrid repair of a Crawford type IV aneurysm is an option that should be considered for patients with good surgical risk profiles and reasonable life expectancy.

\section{REFERENCES}

1. Patel R, Conrad MF, Paruchuri V, Kwolek CJ, Chung TK, Cambria RP. Thoracoabdominal aneurysm repair: Hybrid versus open repair. J Vasc Surg. 2009;50(1):15-22. PMid:19563950. http:// dx.doi.org/10.1016/j.jvs.2008.12.051

2. Wong DR, Parenti JL, Green SY, et al. Open repair of thoracoabdominal aortic aneurysm in the modern surgical era: contemporary outcomes in 509 patients. J Am Coll Surg. 2011;212(4):569-81. PMid:21463791. http://dx.doi. org/10.1016/j.jamcollsurg.2010.12.041

3. Hughes GC, Barfield ME, Shah AA, et al. Staged total abdominal debranching and thoracic endovascular aortic repair for thoracoabdominal aneurysm. J Vasc Surg. 2012;56(3):621-9. PMid:22575483. http://dx.doi.org/10.1016/j.jvs.2011.11.149

4. Patel HJ, Upchurch GR, Eliason JL, et al. Hybrid debranching with endovascular repair for thoracoabdominal aneurysms: a comparison with open repair. Ann Thorac Surg. 2010;89(5):1475-81. PMid:20417763. http://dx.doi. org/10.1016/j.athoracsur.2010.01.062

5. Jenkins MP. Part one: treatment of type IV thoracoabdominal aneurysms: hybrid technique with debranching is the best option. Eur J Vasc Endovasc Surg. 2011;42(1):1-4. PMid:21704875. http:// dx.doi.org/10.1016/j.ejvs.2011.04.003
6. Quiñones-Baldrich WJ, Panetta TF, Vescera CL, Kashyap VS. Repair of type IV thoracoabdominal aneurysm with a combined endovascular and surgical approach.J Vasc Surg. 1999;30(3):555-60. http://dx.doi.org/10.1016/S0741-5214(99)70084-4

7. Chiesa R, Melissano G, Civilini E, Setacci F, Tshomba Y, Anzuini A. Two-stage combined endovascular and surgical approach for recurrent thoracoabdominal aortic aneurysm. J Endovasc Ther. 2004;11(3):330-3. PMid:15174918. http://dx.doi. org/10.1583/03-1145.1

8. Pieper CC, Meyer C, Verrel F, Schild HH, Wilhelm KE. Using the multilayer stent as a supplement to EVAR in combined abdominal aortic aneurysm and iliac artery aneurysm with inadequate distal landing zone: a case report. Vasc and Endovasc Surg. 2012;46(7):565-9. http://dx.doi. org/10.1177/1538574412456306

9. Ohrlander T, Sonesson B, Ivancev K, Resch T, Dias N, Malina $M$. The chimney graft: A technique for preserving or rescuing aortic branch vessels in stent-graft sealing zones. J Endovasc Ther. 2008;15(4):427-32. PMid:18729550. http://dx.doi. org/10.1583/07-2315.1

10. Verhoeven EL, Vourliotakis G, Tielliu IF, et al. Fenestrated Stent grafting for short-necked and justarenal abdominal aortic aneurysm: an 8-year single-centre experience. Eur J Vasc Endovasc Surg. 2010;39(5):529-36. PMid:20202868. http://dx.doi. org/10.1016/j.ejvs.2010.01.004.

11. Amato ACM, Abraham FA, Kraide HD, Rocha LT, Santos RV. Endotensão: ruptura de aneurisma de aorta abdominal. J Vasc Bras. 2012;11(2):162-65. http://dx.doi.org/10.1590/ S1677-54492012000200016

12. Criado FJ, Duson S. The history of snorkel, chimney, periscope and sandwich grafting compared with fenestrated and branched endografting. In: Ferris $M$, editor. Vascular and endovascular challlenges update. 1th ed. London: BIBA; 2013. p. 449.

13. Huynh TT, Miller CC 3rd, Estrera AL, Sheinbaum R, Allen SJ, Safi HJ. Determinants of hospital length of stay after thoracoabdominal aortic aneurysm repair. J Vasc Surg. 2002;35(4):648-53. PMid:11932657. http://dx.doi.org/10.1067/mva.2002.121566

14. Quinones-Baldrich WJ. Descending thoracic and thoracoabdominal aortic aneurysm repair: 15 year results using a uniform approach. Ann Vasc Surg. 2004;18(3):335-42. PMid:15354636. http://dx.doi.org/10.1007/s10016-004-0033-6

15. Roselli EE, Greenberg RK, PfaffK, Francis C, Svensson LG, Lytle BW. Endovascular treatment of thoracoabdominal aortic aneurysms. J Thorac Cardiovasc Surg. 2007;133(6):1474-82. PMid:17532942. http://dx.doi.org/10.1016/j.jtcvs.2006.09.118

16. Greenberg RK, Lu Q, Roselli EE, et al. Contemporary analysis of descending thoracic and thoracoabdominal aneurysm repair: a comparison of endovascular and open techniques. Circulation. 2008;118:808-17. PMid:18678769. http://dx.doi. org/10.1161/CIRCULATIONAHA.108.769695

17. Verhoeven E, Tielliu IF, Zeebregts C), et al. Bericht über die ersten 50 endovaskulären thorakoabdominellen Behandlungen mit Seitenastprothesen. Zentrabl Chir. 2011;136(5):451-57. PMid:21766273. http://dx.doi.org/10.1055/s-0031-1271550

18. Guillou M, Bianchini A, Sobocinski J, et al. Endovascular treatment of thoracoabdominal aortic aneurysms. J Vasc Surg. 2012;56(1):65-73. PMid:22560310. http://dx.doi. org/10.1016/j.jvs.2012.01.008 


\section{Correspondence}

Abdo Farret Neto

Clínica Endovasc, Hospital do Coração Rua Auris Coelho, 235, $2^{\circ}$ andar - Lagoa Nova

CEP 59075-050 - Natal (RN), Brazil Tel.: +55 (84) 41410941 Fax: +55 (84) 3234-0125

E-mail: abdo.farret@gmail.com

Author information

AFN é Angiologista, Cirurgião Vascular e Angiorradiologista. Titular do Colégio Brasileiro de Cirurgiões (TCBC) e Titular da Sociedade Brasileira de Angiologia e Cirurgia Vascular (TSBACV).

Angiorradiologista e Cirurgião Vascular do Hospital Onofre

Lopes. Professor de Doenças do Sistema Cardiovascular na Universidade Federal do Rio Grande do Norte (UFRN). Doutor em Desenvolvimento e Inovação Tecnológica em Medicamentos pela

LBFO é Angiologista, Cirurgiã Vascular e Angiorradiologista. Cirurgiã Vascular do Hospital Onofre Lopes.

GTAA é Residente em Cirurgia Geral do Hospital Onofre Lopes. GAPA é Acadêmico de Medicina da Universidade Federal do Rio Grande do Norte (UFRN).

EDBF é Angiologista e Cirurgião Vascular do Hospital Onofre Lopes. Professor de Doenças do Sistema Cardiovascular na Universidade Federal do Rio Grande do Norte (UFRN).

Author contributions Conception and design: AFN Analysis and interpretation: AFN Data collection: GTAA, GAPA Writing the article: AFN Critical revision of the article: EDBF, LBFO Final approval of the article*: AFN, GTAA, GAP, EDBF, LBFO Statistical analysis: N/A Overall responsibility: AFN Obtained funding: None.

* All authors have read and approved of the final version of the article submitted to J Vasc Bras. 